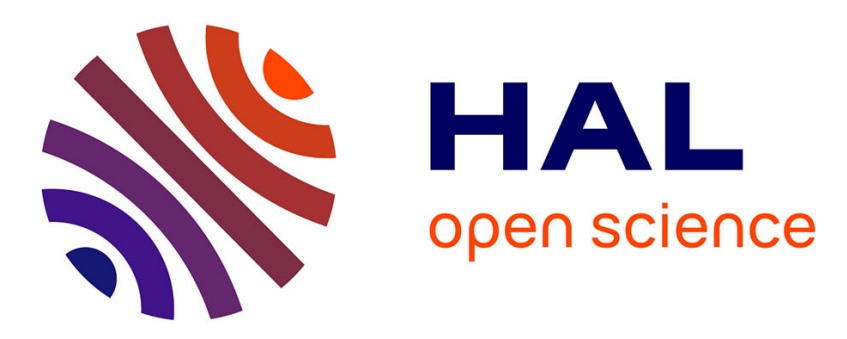

\title{
Acetylcholinesterase activity in Clytia hemisphaerica (Cnidaria)
}

Elsa E. Denker, Arnaud Chatonnet, Nicolas N. Rabet

\section{To cite this version:}

Elsa E. Denker, Arnaud Chatonnet, Nicolas N. Rabet. Acetylcholinesterase activity in Clytia hemisphaerica (Cnidaria). Chemico-Biological Interactions, 2008, 175 (1-3), pp.125-128. 10.1016/j.cbi.2008.03.004 . hal-01004092

\section{HAL Id: hal-01004092 \\ https://hal.science/hal-01004092}

Submitted on 31 May 2020

HAL is a multi-disciplinary open access archive for the deposit and dissemination of scientific research documents, whether they are published or not. The documents may come from teaching and research institutions in France or abroad, or from public or private research centers.
L'archive ouverte pluridisciplinaire HAL, est destinée au dépôt et à la diffusion de documents scientifiques de niveau recherche, publiés ou non, émanant des établissements d'enseignement et de recherche français ou étrangers, des laboratoires publics ou privés. 


\title{
Acetylcholinesterase activity in Clytia hemisphaerica (Cnidaria)
}

\author{
Elsa Denker ${ }^{\mathrm{a}}$, Arnaud Chatonnet ${ }^{\mathrm{b}}$, Nicolas Rabet ${ }^{\mathrm{a}, *}$ \\ a Équipe Evolution et Développement, UMR 7138, Université Pierre et Marie Curie, Paris, France \\ b INRA, UMR 866 INRA, Université Montpellier 1 \& 2, France
}

\section{A R T I C L E I N F O}

\section{Article history:}

Available online 21 March 2008

\section{Keywords:}

Cnidarian

Clytia hemisphaerica

Acetylcholine

Acetylcholinesterase

Neuroligin

\begin{abstract}
A B S T R A C T
Cholinesterase activity is known in representatives of all living organisms phyla but the origin of the cholinergic system as known in bilaterian animals is still undeciphered. In particular the implication of cholinesterases in the nervous system of non-bilaterian Metazoa is not well known. We thus chose to investigate this activity in the Clytia hemisphaerica (Cnidaria) medusa. In toto histochemical staining revealed an acetylcholinesterase activity in the tentacle bulbs but not in the nervous system. Sequences homologous to acetylcholinesterase were searched within Clytia ESTs and compared to other sequences found in public databases.
\end{abstract}

(c) 2008 Elsevier Ireland Ltd. All rights reserved.

\section{Introduction}

Acetylcholine (ACh) is well known as an important neurotransmitter in the nervous systems of several groups of bilaterians (bilaterally symmetrical organisms, corresponding to all animals except sponges, cnidarians and ctenophores) and is especially studied in insects and in vertebrates [1]. ACh and the cholinergic pathway have also been detected in various life forms, such as bacteria, plants, fungi and various other metazoans [1,2]. These findings suggest that $\mathrm{ACh}$ has been used by organisms well before the appearance of the first nervous systems. Moreover, ACh has been detected in several types of non-neuronal cells in mammalian species [4-6] perhaps representing a part of a legacy from an ancestor without a nervous system. More generally, the integration of the cholinergic pathway in the nervous system is a very relevant topic in order to decipher how the nervous system appeared. From this point of view, cnidarians and ctenophores are very important because they are the only non-bilaterian animals with a nervous system. In cnidarians (jellyfishes, corals, anemones, hydras, etc.) acetylcholinesterase activity was only localized in

\footnotetext{
* Corresponding author.

E-mail address: nicolas.rabet@snv.jussieu.fr (N. Rabet).
}

Hydra in the cell bodies and neurites of putative ganglion cells, nematocytes and also in epitheliomuscular and digestive cells [7]. Despite the histochemical evidence for this activity in Hydra and more generally in cnidarians the implication of ACh as a neurotransmitter remains equivocal [8-10]. We chose to investigate the cholinesterase activity in medusae of Clytia hemisphaerica (Cnidaria, Hydrozoa) and to look for potential candidate genes by sequence comparison.

\section{Materials and methods}

For all experiments we used $C$. hemisphaerica medusae cultured in Paris as described in [11], except that artificial seawater was used (36 g/l Reef Crystals ${ }^{\circledR}$, Aquarium Systems).

Whole-mount histochemical staining was obtained on medusae and gonozoids, fixed in $4 \%$ paraformaldehyde at $24{ }^{\circ} \mathrm{C}$ for $30 \mathrm{~min}$. The staining was obtained by the Karnovsky and Roots [12] method, using acetylthiocholine iodide as substrate. Specific inhibition of AChE was obtained with eserine $\left(10^{-4} \mathrm{M}\right)$.

Enzyme activity was measured according to the method of Ellman et al. [13] (0.1 M potassium phosphate buffer $\mathrm{pH}$ 7.0, $0.5 \mathrm{mM}$ DTNB $1 \mathrm{mM}$ acetylthiocholine) on homogenates of 20 medusae extracted in 10 volumes of 
ice cold extraction buffer $(50 \mathrm{mM}$ potassium phosphate, $\mathrm{pH} 7.5$ ) in glass-glass potter. Samples were incubated in dilutions of $1 \mathrm{nM}$ to $1 \mathrm{mM}$ eserine (Sigma). The remaining activity was expressed relative to the initial activity.
The Clytia genes were retrieved by BLAST searches (expect value: 0.0001) with known bilaterian AChE on an unpublished EST collection sequenced by the Genoscope (Evry, France) from a Clytia normalized cDNA
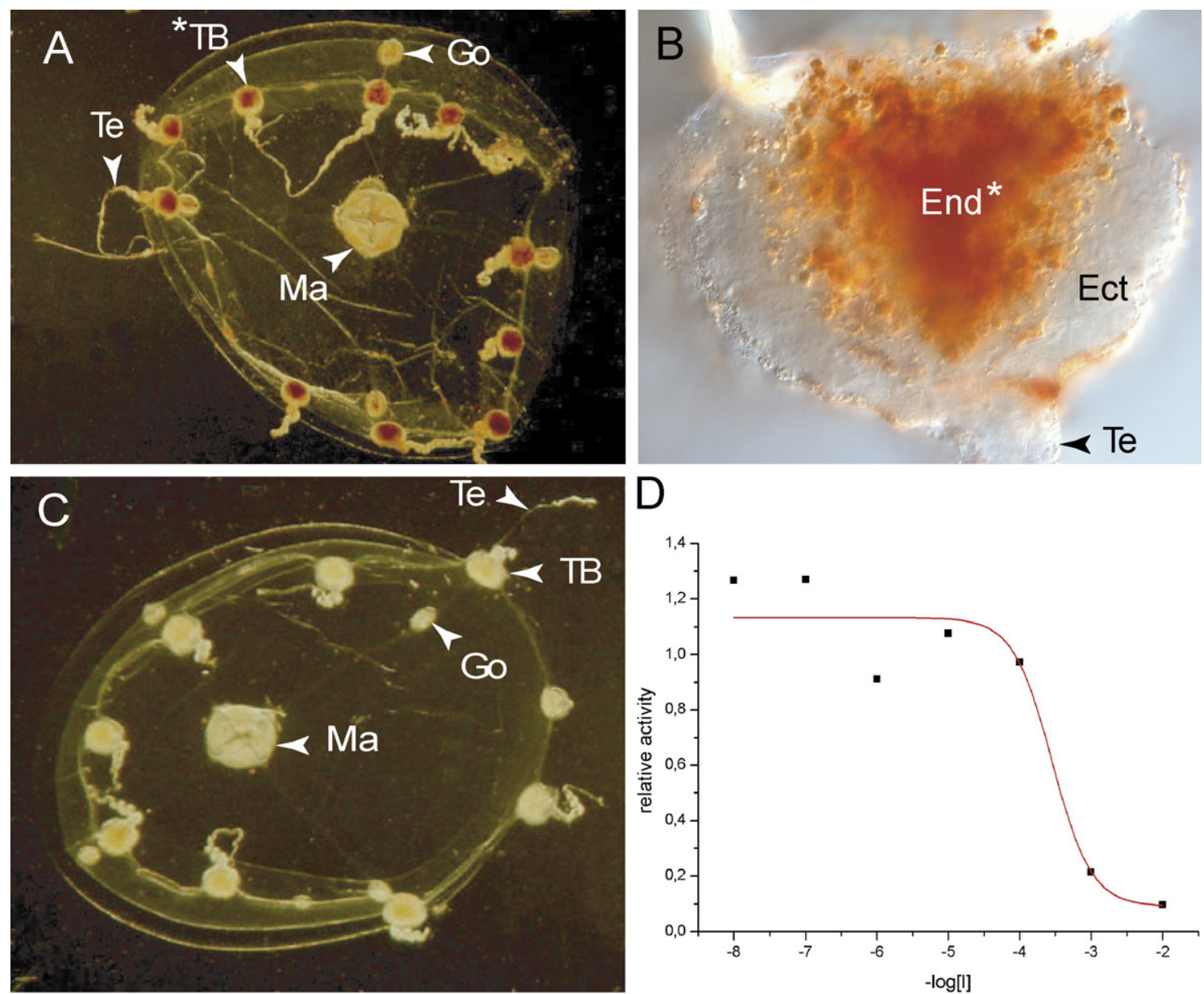

D

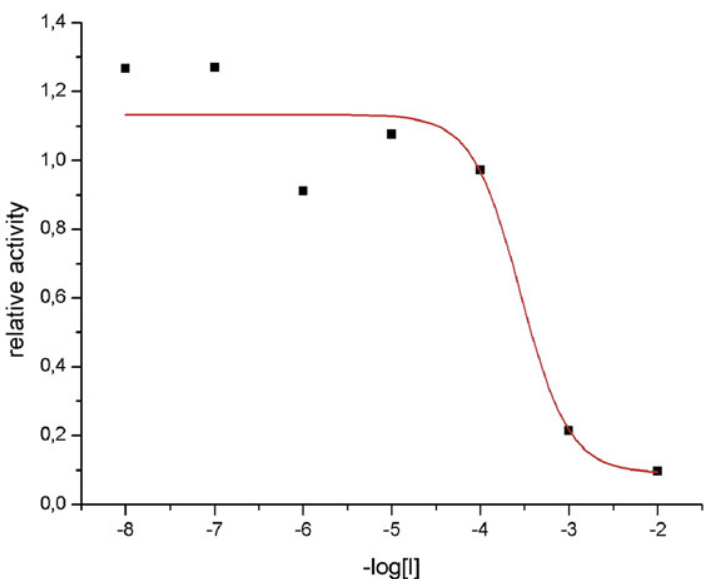

\section{E}

Human-acche Human-buche Lolop-ache1 Brafl-achel Brafl-ache2 Anost-ache 1 Anost-ache 2 Chick-acche Chick-buche Checx 1

Checx 2

Checx 3

Human-neuro
(97) OSVCYOYVDT . . (116) • MWNPNR---ELSEDCLY . • (147) • VWIYGGGFYSG--ASSLDVYD . (232) • GESAG
(131) ANSCCQNIDQ - (150) • MWNPNT---DLSEDCLY . (180) • IWIYGGGFQTG--TSSLHVYD . (265) • GESAG
(89) PNSCIOGFDR . (108) • MWHANT---QLSEDCLY . . (140) • VWIYGGGFYSG--TSTLDVYD . . (224) • GESAG
(82) PNSCVSAPDE - •(101) • MWNPNT---PISEDCLY . (131) •VWIYGGGFFSG--TSSLDVYD • (215) • GESAG
(89) PNTCMQLPDT . (108) . MWNPNT---PVSEDCLY . (138) • VWIYGGGFMSG--TSSLDVYD . (222) . GESAG
(225) PNSCVQIVDT . (244) • MWNPNT---PLSEDCLY . (274) •LWIFGGGFYSG--TATLDVYD . (358) • GESAG
(94) PPSCIQERYE . - (113) • MWNPNT---NVSEDCLY • • (171) • VWIYGGGFMSG--TSTLDIYN . • (261) • GESAG
(91) PFACYOMVDT . (110) . MWNPNR---EMSEDCLY . . (140) • VWIYGGGFTGG--SVSLDVYD . . (225) • GESAG
(90) ANSCYQLIDT . . (109) . MWNPKT---NLSEDCLY . . (139) • VWIYGGSFETG--STSLPVYD . (224) . GESAG
(147) NTLCIQYNPP . (163) . - - (189) • VWI HG-GFLLNVYSDVPGYYP . (280) . GESSG
(79) PPMCSQDAAG . . (100). KESIP---LTFSEDCLY . . (132) . VWI HGGGLM----VGGASTYS . . (214) . GESAG
(101) PAQCWDGVLK . (123) . PFTPS---VNTSEDCLV . (154) . VWI HGGGMLW-GYNEMFAFHP . (246) . GESGG
(114) APVCPQNIID..(139) •LDVVSSYVQDQSEDCLY . (177) •VYIHGGSYM----EGTGNLYD . (259) • GSGAG $* *$

Fig. 1. (A-B) Whole-mount histochemical staining of AChE activity. Asterisk $\left(^{*}\right)$ indicates specific staining; TB: tentacle bulb; Ect: bulb ectoderm; End: bulb endoderm; Go: Gonad; Ma: manubrium; Te: tentacle. (A) Whole medusa without eserine; (B) detail of bulb without eserine; (C) whole medusa with eserine; (D) extent of inhibition of acetylthiocholine hydrolysis by increasing concentration of eserine (remaining activity is expressed relative to the initial activity without eserine). (E) Alignment of partial sequences of Clytia genes candidates for cholinesterase activity (Che-Cx1, -2 , and -3: Clytia hemisphaerica putative carboxylesterases 1, -2, and -3). Informative positions are indicated. (a) Peripheral anionic site; (b) choline binding site; (c-e) aromatic residues in catalytic gorge; (f) active site serine. Human-AChE: human acetylcholinesterase (AAH94752); Human-BuChE: human butyrylcholinesterase (EAW78592); ChickAChE: chicken acetylcholinesterase (P36196); Chick-BuChe: chicken butyrylcholinesterase (NP_989977); Lolop-AChE1: opal squid acetylcholinesterase (AAD15886); Brafl-AChE1 and -2: florida lancelet acetylcholinesterase 1 (AAD05373) and -2 (AAD05374); Anoga-AChE1 and -2: Anopheles gambiae mosquito acetylcholinesterase 1 (XP_321792) and -2 (XP_310628); Human-neuro: human neuroligin 1 (NP_055747). Asterisk( $\left.{ }^{*}\right)$ indicates conserved position. Disulfide bonds are indicated by a line. Numbers in parenthesis indicate the amino acid position starting from the beginning of sequences. 
library [11]. The library was constructed by Express Genomics (Frederick, Maryland, USA) in pExpress1 from total mRNA extracted from a mixture of all stages of the life cycle.

Sequences of the three Clytia genes were registered in GenBank under the accession numbers AM902710 (Checx1), AM902711 (Checx2), and AM902712 (Checx3). Other bilaterian sequences were found in GenBank. Sequences were automatically aligned using CLUSTALW in BioEdit (Tom Hall, Ibis Therapeutics, Carlsbad, CA) and the alignment was corrected manually. The identity of each position was established following the database ESTHER [14].

\section{Results}

AChE activity was detected in the endoderm of the tentacle bulbs which are structures located at the base of the tentacles (Fig. 1A and B). This activity was found whatever the stage of development of the bulb in the free medusae and also in forming medusae inside the gonozoid polyp (data not shown). This activity can be inhibited by eserine (compare Fig. $1 \mathrm{C}$ with $\mathrm{A}$ ) at concentrations above $10^{-4} \mathrm{M}$ (Fig. 1D).

Blast searches on our EST collection allowed us to identify three genes from neuroligin-cholinesterase family in Clytia. The best conserved regions of these putative Che-Cx1, Che-Cx2 and Che-Cx3 proteins were found to correspond to the aminoacids $124-236$ of human AchE, presenting, respectively, $40 \%, 52 \%$ and $43 \%$ identity as well as $56 \%, 68 \%$ and $59 \%$ conservation with the latter, clearly excluding random similarities. A partial alignment of these three sequences with bilaterian sequences known for their enzymatic activity is presented, showing catalytic positions (Fig. 1E). Among the selection of available positions, some aromatics residues in the catalytic gorge and the active site serine seem to be conserved, suggesting that these proteins could have a cholinesterase activity.

\section{Discussion}

Before this study, numerous and various experiments suggested the existence of a cholinergic system in different cnidarians (review in [15]). However it is the first time, to our knowledge, that a localization of cholinesterase activity is described in a medusa. The only other reference, cited by Scemes [15], was never published. Whole-mount activity assays published before this study only concerned Hydra and showed that this cholinesterase activity existed in various cell types including nerve cells [7]. However these results were not reproduced in more recent studies and should be interpreted as non-specific esterases [8].

The endodermal cholinesterase activity suggests that the cholinergic system in Clytia is not related to the nervous system. More generally, no experiment clearly supports the idea that $\mathrm{ACh}$ is used as a neuromediator in cnidarians $[10,16]$. Two interpretations for this apparent absence of function can be considered: either the cholinergic system was secondarily recruited for the nervous system in the bilaterian lineage or this function was lost in the cnidarian lineage.
The endodermal acetylcholinesterase of Clytia is localized in one of the most active organs of the medusa, the tentacle bulb. It could be reminiscent of the non-neural cholinergic system recently studied in mammalian or in non-metazoan organisms where $\mathrm{ACh}$ is involved in regulating physiological functions as a local mediator $[1,3]$.

As it was recently shown [17], the cholinesterase function could be performed by several non-homologous families suggesting that this function was recruited several times independently. Nothing is known on this subject in cnidarians. In order to identify the gene at the origin of the cholinergic activity in Clytia, complementary analyses are necessary. Co-localization of the expression patterns of candidate genes with AChE activity remains to be demonstrated, moreover the activity of the proteins encoded by these genes should be directly investigated.

\section{Acknowledgements}

We would like to thank Alexandre Alié for critical reading of the manuscript. This work was supported by grants from the French Ministry of Research (ACI jeunes chercheurs), and a grant from the GIS "Institut de la Génomique Marine"-ANR blanche NT_NV_52. We thank the Consortium National de Recherche en Génomique and the Genoscope (Evry, France) for sequencing ESTs from $C$. hemisphaerica.

\section{References}

[1] Y. Horiuchi, R. Kimura, N. Kato, T. Fujii, M. Seki, T. Endo, T. Kato, K. Kawashima, Evolutional study on acetylcholine expression, Life Sci. 72 (2003) 1745-1756.

[2] X. Cousin, U. Strähle, A. Chatonnet, Are there non-catalytic functions of acetylcholinesterases? Lessons from mutant animal models, BioEssays 27 (2005) 189-200.

[3] K. Kawashima, H. Misawa, Y. Moriwaki, Y.X. Fujii, T. Fujii, Y. Horiuchi, T. Yamada, T. Imanaka, M. Kamekura, Ubiquitous expression of acetylcholine and its biological functions in life forms without nervous systems, Life Sci. 80 (2007) 2206-2209.

[4] H. Klapproth, T. Reinheimer, J. Metzen, M. Munch, F. Bittinger, C.J. Kirkpatrick, K.D. Hohle, M. Schemann, K. Racke, I. Wessler, Non-neuronal acetylcholine, a signalling molecule synthesized by surface cells of rat and man, Naunyn Schmiedebergs Arch. Pharmacol. 355 (1997) 515-523.

[5] I. Wessler, H. Kilbinger, F. Bittinger, C.J. Kirkpatrick, The biological role of non-neuronal acetylcholine in plants and humans, Jpn. J. Pharmacol. 85 (2001) 2-10.

[6] I. Wessler, H. Kilbinger, F. Bittinger, R. Unger, C.J. Kirkpatrick, The nonneuronal cholinergic system in humans: expression, function and pathophysiology, Life Sci. 72 (2003) 2055-2061.

[7] T. Lentz, R.J. Barrnett, Enzyme histochemistry of Hydra, J. Exp. Zool. 147 (1961) 125-149.

[8] I. Eržen, M. Brzin, Cholinergic mechanisms in Hydra, Comp. Biochem. Physiol. C 59 (1978) 39-43.

[9] E. Scemes, E. Garcia Mendes, Cholinergic mechanism in Liriope tetraphylla (Cnidaria, Hydrozoa), Comp. Biochem. Physiol. C 83 (1986) 171-178.

[10] G. Kass-Simon, P. Pierobon, Cnidarian chemical neurotransmission, an updated overview, Comp. Biochem. Physiol. A Mol. Integr. Physiol. 146 (2007) 9-25.

[11] S. Chevalier, A. Martin, L. Leclere, A. Amiel, E. Houliston, Polarised expression of FoxB and FoxQ2 genes during development of the hydrozoan Clytia hemisphaerica, Dev. Genes Evol. 216 (2006) 709-720.

[12] M.J. Karnovsky, L. Roots, A direct coloring method for cholinesterases, J. Histochem. Cytochem. 12 (1964) 219-221.

[13] G.L. Ellman, K.D. Courtney, V. Andres Jr., R.M. Feather-Stone, A new and rapid colorimetric determination of acetylcholinesterase activity, Biochem. Pharmacol. 7 (1961) 88-95. 
[14] T. Hotelier, L. Renault, X. Cousin, V. Negre, P. Marchot, A. Chatonnet, ESTHER, the database of the $\alpha / \beta$-hydrolase fold superfamily of proteins, Nucleic Acids Res. 32 (2004) D145-D147.

[15] E. Scemes, Rethinking the role of cholinergic neurotransmission in the Cnidaria, in: P.A.V. Anderson (Ed.), Evolution of the First Nervous Systems, Plenum Press, New York, 1989, pp. 157-166.
[16] C.J.P. Grimmelikhuijzen, M. Williamson, G.N. Hansen, Neuropeptides in cnidarians, Can. J. Zool. 80 (2002) 1690-2170.

[17] Y. Sagane, T. Nakagawa, K. Yamamoto, S. Michikawa, S. Oguri, Y.S. Momonoki, Molecular characterization of maize acetylcholinesterase: a novel enzyme family in the plant kingdom, Plant Physiol. 138 (2005) 1359-1371. 